\title{
Effects of Cecropin Peptides on Aquatic Animal Pathogens and Shrimp Hemocytes
}

\author{
Shih-Hu Ho ${ }^{1}$, Chia-Zong Lin ${ }^{2}$, Yu-Chih Chen ${ }^{1}$ and Yen-Ling Song ${ }^{1 *}$ \\ ${ }^{1}$ Department of Zoology and \\ ${ }^{2}$ Institute of Fisheries Science, National Taiwan University, \\ Taipei, Taiwan, 106, Republic of China
}

(Received May 31, 2001)

\begin{abstract}
In this paper, the effects of the well-characterized antimicrobial amphipathic peptides (cecropins $\mathrm{A}$ and $\mathrm{P} 1$ ) on pathogens of aquatic organisms were assessed. Results showed that cecropins inhibited growth of 15 strains of bacteria, including Gram-negative bacteria: Aeromonas hydrophila, A. salmonicida, Photobacterium damselae subsp. damselae, Pseudomonas anguilliseptica, Vibrio alginolyticus, $V$. anguillarum, V. carchariae, V. harveyi, V. ordalii, $V$. parahaemolyticus, $V$. tubiashii and $V$. vulnificus biogroup I. Cecropins also inhibited growth of two strains of the yeast Debaryomyces hanseni, pathogenic to freshwater prawn Macrobrachium rosenbergii. Minimum inhibitory concentration (MIC) of cecropin A ranged from 0.98 to $7.81 \mu \mathrm{M}$ and minimum bactericidal concentration (MBC) ranged from 3.90 to $15.59 \mu \mathrm{M}$ against the most prevalent vibrios pathogenic to cultured shrimp. A higher level of cecropin was required in a high salt environment to exhibit the effect against the pathogens. Influence of $\mathrm{NaCl}$ on bactericidal activity of cecropin A was also assayed. ${ }^{51} \mathrm{Cr}$-release assay showed a non-cytotoxic effect of cecropin A on shrimp (Penaeus monodon) hemocytes at MBC, but cytotoxic effect at $50 \mu \mathrm{M}$ (3.2fold $\mathrm{MBC}$ ) or higher concentration. This suggests that cecropin peptides may be difficult to be applied in vivo to treat infected marine shrimp.
\end{abstract}

Key words: cecropin, antimicrobial activity, Penaeus monodon, MIC, MBC, cytotoxic effect, hemocyte

Shrimp culture industry faces a crisis of production due to diseases all over the world. Nearly 20 distinct viruses, many Vibrio species and filamentous bacteria, several fungal and peritrich protozoan agents have been identified from diseased shrimp (Song et al., 1990; Song and Lee, 1993; Bower et al., 1994; Karunasagar et al., 1998; Lavilla-Pitogo and de la Peña, 1998; Lightner and Redman, 1998; Takahashi et al., 1998). It is common for a shrimp to be infected simultaneously with multiple pathogens. Recent documents show that some shrimp diseases resulted from co-infection by several viruses (Munday and Owens, 1998; Wang and Chang, 2000). Increasing the non-specific immunity to provide shrimp with a broad-spectrum defensive ability may effectively and practically protect them from infection.

Animal peptide antibiotics are widespread in nature, occurring in mammals (Lee et al., 1989), amphibians (Zasloff, 1987), fish (Cole et al., 1997), insects (Boman,

\footnotetext{
* Corresponding author

E-mail: song@ccms.ntu.edu.tw
}

1991) and crustaceans (Destoumieux et al., 1997). These peptides are major constituents of the innate immune system for non-specific defense of the host against microbial invaders. This type of defense can be rapidly activated after injury or invasion of the host by microbial agents. This is done by combating parasitic growth immediately after infection. Antimicrobial peptides thus provide an important defense mechanism in animals and the first line of host defense during the time required for mobilization of specific immunity in vertebrates.

Cecropins, the highly basic and amphipathic small peptides, have been induced and isolated from insects (Hultmark et al., 1980; Hoffmann et al.,1981; Flyg et al., 1987; Matsumoto et al., 1986; Dickinson et al., 1988) and porcine (Lee et al., 1989). They have broad-spectrum bactericidal activity. In the past, many researchers reported that cecropins could inhibit the growth of bacteria, both Gram positive and Gram negative (Qu et al., 1982; Lee et al., 1989). Synthesized cecropins have also been reported active against bacteria that are 
pathogenic to plants (Nordeen et al., 1992) and insects (Hultmark et al., 1982). At lethal concentrations, they are active against protozoa, fungi, enveloped viral pathogens and cancer cells without apparent deleterious effect on host cells. Chalk et al. (1995) reported that cecropin could attenuate the motility of microfilariae, Brugia pahangi, a human pathogenic nematoda. However, only one paper has been documented in relation to the antimicrobial activities of cecropin peptides on fish pathogens including four bacterial species (Kjuul et al., 1999). Neither the antimicrobial activity of the peptides on the pathogens of the other aquatic organisms such as bivalves and crustaceans nor the cytotoxic effect has been assessed for therapeutic purpose.

It will be of interest to see whether such peptides, when expressed or given passively in vivo, will play safely a protective role in cultured shrimp. In the present study, cecropins were assessed in terms of its in vitro antimicrobial activity against some prevalent aquatic pathogens using a radial diffusion assay. Effect of salinity on the bactericidal activity of cecropin was also evaluated using a plate count method. Minimal inhibitory concentration and minimal bactericidal concentration of cecropin on Vibrio and cytotoxic concentration of cecropin on shrimp hemocytes using a ${ }^{51} \mathrm{Cr}$-release assay were also measured.

\section{Materials and Methods}

\section{Bacterial and yeast culture}

Twenty-three bacterial strains and two yeast strains were collected for this study. It comprised of 18 species and 8 genera. The bacterial strains were grown in tryptone soya broth (TSB, Oxoid), except Aeromonas salmonicida and Vibrio strains which were cultured in the same medium supplemented with $2.5 \% \mathrm{NaCl}$. Escherichia coli strains were maintained in Lennox $\mathrm{L}$ broth (LB, Acumedia). Debaryomyces hansenii was grown in yeast malt broth (YMB, Difco). All strains were incubated with shaking at $28^{\circ} \mathrm{C}$ but $E$. coli at $37^{\circ} \mathrm{C}$. Cells were prepared for testing when they grew to midlog phase, i.e. absorption value equals to 0.55 at $595 \mathrm{~nm}$ in wavelength using a spectrophotometer (DigiSpec, Helena Laboratories). The concentration of the culture was then measured to be $10^{8} \mathrm{CFU} / \mathrm{mL}$ using a plate count method.

\section{Radial diffusion method}

The diffusion method was done mainly according to Hultmark et al. $(1982,1983)$. Culture plates were made on a leveling table from $6.8 \mathrm{~mL}$ of the melting $\mathrm{LB}$ agarose (LBA, $1 \%$ ) and the final concentration of cultured cells was $10^{5} \mathrm{CFU} / \mathrm{mL}$. E. coli strains such as D21, D31 and JM107, the cecropin-susceptible strains, were used as the positive bacterial control. Micrococcus lysodeikticus (Sigma, ATCC4698), the cecropin-non- susceptible strain, was used as the negative bacterial control. Lysozyme (purified from chicken egg white, Sigma) cleaving $\beta$-(1,4)-glycosidic bonds in the peptidoglycan layer of Gram positive bacterial cell wall was used as antimicrobial peptide control. Wells were punched $3 \mathrm{~mm}$ in diameter on the harden LBA plate. Four $\mu \mathrm{L}$ sample of cecropin $\mathrm{A}(62 \mu \mathrm{M}$, synthetic silkworm peptide, Sigma), cecropin P1 (75 $\mu \mathrm{M}$, synthetic porcine peptide, Sigma) or lysozyme $(280 \mu \mathrm{M})$ was loaded into wells. Plates were read following overnight incubation at $28 / 37^{\circ} \mathrm{C}$ using a dissecting microscope. Two diameter readings at $90^{\circ}$ angles were taken. Positive inhibitory response was defined as the area of the clear zone being bigger than the area of the well.

\section{Broth microdilution assay of antimicrobial activity}

Doubling dilutions of cecropin A stock solution (1000 $\mu \mathrm{g} / \mathrm{mL}$ ) were made in LB or TSB broth. Bacterial suspension of each strain was diluted to a final concentration of $10^{5}-10^{6} \mathrm{CFU} / \mathrm{mL}$ in LB or TSB. Cecropin solution in each dilution was mixed with an equal volume of bacterial suspension and each strain was made in triplicates. Turbidity of bacterial suspension was observed by naked eyes after incubation for $16-20 \mathrm{~h}$ at $28^{\circ} \mathrm{C}$. Minimal inhibitory concentration (MIC) was defined as the lowest concentration (the highest dilution) of cecropin that inhibited bacterial growth in the mixture. Minimal bactericidal concentration (MBC) was further determined by culturing the clear broth on TSA plates in triplicates. MBC was defined as the lowest concentration of cecropin that reduced bacterial colonies by $99.9 \%$.

\section{$\mathrm{NaCl}$ susceptibility testing}

Each one strain of $V$. harveyi (W36G) and $V$. alginolyticus (Val) were selected and cells were grown in aerated TSB supplemented with different concentrations of $\mathrm{NaCl}$ at $0.1 \mathrm{M}, 0.3 \mathrm{M}$ and $0.5 \mathrm{M}$. The peptide concentration was chosen as about three-fold the MIC value of cecropin $A$ when tested against the respective pathogen and was the same for all the killing studies conducted. The killing rate tests were started by adding peptide to a final concentration of $5.0 \mu \mathrm{M}$ for $V$. harveyi and $2.5 \mu \mathrm{M}$ for $V$. alginolyticus, in a volume of $1 \mathrm{~mL}$ diluted culture $\left(10^{5}\right.$ cells $\left./ \mathrm{mL}\right)$. The cells were incubated with shaking at $25^{\circ} \mathrm{C}$. At intervals, $50 \mu \mathrm{L}$ samples were withdrawn and directly, or after dilution in TSB (3\% $\mathrm{NaCl}$ ), plated on TSA agar plates. Colony forming units (CFUs) were counted after overnight incubation at $28^{\circ} \mathrm{C}$.

\section{Experimental shrimp}

Apparently healthy tiger shrimp (Penaeus monodon) weighing $10-20 \mathrm{~g}$ each were purchased from a local hatchery. They were kept in a plastic tank $(75 \times 45 \times 45$ $\mathrm{cm}^{3}$ ) supplied with 100-L constant flow of recirculating brackishwater at $20 \mathrm{ppt}$ salinity, $25^{\circ} \mathrm{C}$ temperature, $80-$ 
$90 \mathrm{ppb}$ ammonia- $\mathrm{N}$ and $10-30 \mathrm{ppb}$ nitrite. Shrimp were stocked at a density of 20-25 individuals per square meter. Synthetic feed pellets equivalent to $5 \%$ of the body weight were fed twice a day and shrimp were conditioned for more than one month before experiment.

\section{Chromium release assay}

Eight tenth $\mathrm{mL}$ of hemolymph was collected using a 1 - $\mathrm{mL}$ syringe containing $0.2 \mathrm{~mL}$ anticoagulant $(0.1 \mathrm{M}$ sodium citrate, $0.4 \mathrm{M}$ sucrose, $0.01 \mathrm{M}$ Tris- $\mathrm{HCl}, \mathrm{pH} 7.6$, $750 \mathrm{mOsm} / \mathrm{kg}$ ) from each of the twenty shrimp. After centrifugation at $300 \times g$ for $10 \mathrm{~min}$, hemocytes were harvested and suspended in $0.5 \mathrm{~mL}$ anticoagulant solution. Chromium release assay was conducted following that of Hogan et al. (1996) with slight modification. Briefly, $0.2 \mathrm{~mL}$ sodium ${ }^{51}$ chromate $(1 \mathrm{mCi} / \mathrm{mL}$, Amersham) was added to $10^{7}$ hemocytes and incubated at room temperature for $2 \mathrm{~h}$. Isotope-labeled hemocytes were washed 3 times at $300 \times g$ centrifugation for $10 \mathrm{~min}$ and then suspended in the anticoagulant solution. Hemocytes were stained with trypan-blue dye and counted using a hemacytometer. The viability of hemocytes was estimated to be $77 \%$. The final concentration of viable hemocytes was adjusted to $10^{7}$ cells/ $\mathrm{mL}$ in anticoagulant.

Completed Hanks' balanced salt solution (CHBSS, Gibco) was supplemented with $10 \mathrm{mM} \mathrm{CaCl}_{2}, 3 \mathrm{mM}$ $\mathrm{MgCl}_{2}$ and $5 \mathrm{mM} \mathrm{MgSO}{ }_{4}$ as the modified CHBSS (MCHBSS) to maintain osmolarity to $750 \mathrm{mOsm} /$ kg. Cecropin A was diluted to $50 \mu \mathrm{M}, 100 \mu \mathrm{M}$ and 150 $\mu \mathrm{M}$ with MCHBSS. Fifty $\mu \mathrm{L}$ of labeled hemocytes was mixed with an equal volume of cecropin solution, or MCHBSS as control. The mixture was incubated at room temperature for $1 \mathrm{~h}$. After centrifugation, $50 \mu \mathrm{L}$ of the supernatant was transferred to a scintillation vial and measured to determine counts per minute (CPM) using a gamma counter (1282 Compugamma, LKB). Fifty $\mu \mathrm{L}$ of MCHBSS or $2 \%$ IGEPAL CA-630 ((octylphenoxy) polyethoxyethanol, Sigma) in replacement of cecropin solution was added to the labeled hemocytes, respectively, to serve as the controls of spontaneous (minimum) and complete (maximum) releases. Percent specific release is defined as $100 \% \times$ (experimental release spontaneous release) / (maximum release - spontaneous release).

\section{Results and Discussion}

Radial diffusion assay showed that cecropins $A$ and P1 could inhibit growth of 15 strains of Gram-negative bacteria. They are Aeromonas hydrophila, A. salmonicida, Photobacterium damselae subsp. damselae, Pseudomonas anguilliseptica, Vibrio alginolyticus, $V$. anguillarum, V. carchariae, $V$. harveyi, $V$. ordalii, $V$. parahemolyticus, $V$. tubiashii and $V$. vulnificus biogroup I. Noticeably these Gram-negative bacteria have al- ready been characterized as the etiological agents of many infectious diseases such as motile aeromonad septicemia, furunculosis, gastroenteritis, red spot disease and vibriosis that cause high mortalities in cultured fishes. Cecropins also inhibited growth of yeast, $D$. hansenii, which is pathogenic to freshwater prawn Macrobrachium rosenbergii (Lu et al., 1998). These results indicate that cecropin peptides provide antimicrobial activity with a broad spectrum, although the growth inhibitory activity was not found against Edwardsiella tarda, Flavobacterium columnare, Flexibacter maritimus and $V$. vulnificus biogroup II (Table 1). Kjuul et al. (1999) reported that Edwardsiella ictaluri was less sensitive to cecropin, which could be attributed to the structure differences in the bacterial cell wall. Zaldivar (1985) found that the outer membrane of $F$. columnare was surrounded by galactosamine-rich secretion in TEM preparations treated with ruthenium red. Whether the high-molecular-weight amino sugars interfere the channel formation and/or blebbing of the outer membrane that are known to be essential steps in the mechanism used by cecropins to kill live bacteria is not clear. Apparently, lysozyme does inhibit growth of Gram-positive bacteria such as Bacillus subtilis ATCC6051 and ATCC6633 (Song and Lin, unpublished data), Micrococcus lysodeikticus and pathogenic yeast strains. Growth inhibitory activity of lysozyme was not found on Gramnegative bacteria although a high dose was applied in the present study. Since most bacterial diseases of cultured aquatic organisms are caused by Gram-negative group, a limited potential will be expected on lysozyme in the treatment of infectious diseases of aquatic organisms.

Although a slight high dose of cecropin P1 was applied in the inhibition zone assay, the results indicated that cecropin $A$ appeared equal or more potent for the 12 among 17 cecropin-susceptible strains tested (Table 1). Consistent conclusions were noted from the previous studies that cecropin A proved more potent than the B form (Samakovlis et al., 1990) and the killing rate was higher for cecropin B than for cecropin P1 (Kjuul et al., 1999). Therefore, we selected cecropin $A$ in the following $\mathrm{MIC}, \mathrm{MBC}, \mathrm{NaCl}$ tolerance and cytotoxic assays. The range of MIC was determined from 0.98 to $7.81 \mu \mathrm{M}$ and MBC from 3.90 to $15.59 \mu \mathrm{M}$ (Table 2) against selected Vibrio strains which are prevalent and pathogenic to cultured shrimp (Song et al., 1990; Song and Lee, 1993; Mohney et al., 1994).

Since lethal concentration value of cecropin B1 measured on $E$. coli using inhibition zone assay in the previous investigation (Morishima et al., 1990) is close to MIC value of cecropin A measured on E. coli using broth microdilution assay in this study, we examined the effect of $\mathrm{NaCl}$. As a result we found that a higher level of cecropin $\mathrm{A}$ was required to inhibit bacterial growth in a salt-supplemented TSB $(3 \% \mathrm{NaCl})$ in comparison with 
Table 1. Effect of antimicrobial peptides on the growth of some pathogens of aquatic organisms using radial diffusion assay

\begin{tabular}{|c|c|c|c|c|c|}
\hline \multirow{2}{*}{ Species } & \multirow{2}{*}{ Strain } & \multirow{2}{*}{ Sourse } & \multicolumn{3}{|c|}{ Area of inhibition zone $\left(\mathrm{mm}^{2}\right)$} \\
\hline & & & Cecropin $A^{a}$ & Cecropin $\mathrm{P} 1^{\mathrm{b}}$ & Lysozyme $^{c}$ \\
\hline Escherichia coli & $\mathrm{D} 21$ & & 184 & 183 & 0 \\
\hline E. coli & D31 & & 170 & 157 & 0 \\
\hline E. coli & JM107 & - & 184 & 190 & 0 \\
\hline Micrococcus lysodeikticus & - & - & 0 & 0 & 393 \\
\hline \multicolumn{6}{|l|}{ Gram negative bacteria } \\
\hline Aeromonas hydrophila & ATCC 7966 & Tin of milk with a fishy odour & 32 & 51 & 0 \\
\hline A. salmonicida & - & - & 85 & 85 & 0 \\
\hline Edwardsiella tarda & 820429-1L & Eel (Anguilla japonica) & 0 & 0 & 0 \\
\hline Flavobacterium columnare & DD3 & $\begin{array}{l}\text { Spring Chinook salmon } \\
\text { (Oncorhynchus tshawytscha) }\end{array}$ & 0 & 0 & 0 \\
\hline Flexibacter maritimus & NCMB2154 ${ }^{\top}$ & red sea bream (Pagrus major) & 0 & 0 & 0 \\
\hline $\begin{array}{l}\text { Photobacterium damselae } \\
\text { subsp. damselae }\end{array}$ & ATCC 33539 & Damselfish (Chromis punctipinnis) & 103 & 44 & 0 \\
\hline Pseudomonas anguilliseptica & АТCC 33660 & Japanese eel (Anguilla japonica) & 112 & 128 & 0 \\
\hline Vibrio alginolyticus & ATCC 17749 & Spoil horse mackerel (Sarda sarda) & 81 & 79 & 0 \\
\hline V. alginolyticus & Val & Diseased shrimp (Penaeus monodon) & 132 & 92 & ND \\
\hline V. anguillarum & ATCC 19264 & Cod (Gadus callaris) & 61 & 92 & 0 \\
\hline V. carchariae & ATCC 35084 & Brown shark (Carcharhinus plumbeus) & 31 & 27 & 0 \\
\hline V. harveyi & ATCC 14126 & Amphipod (Talorchestia sp.) & 33 & 46 & 0 \\
\hline V. harveyi & $13 b$ & Diseased shrimp ( $P$. monodon) & 209 & 142 & ND \\
\hline V. harveyi & W36G & Diseased shrimp ( $P$. monodon) & 140 & 140 & ND \\
\hline V. ordalii & ATCC 33509 & Coho salmon (Oncorhynchus kisutch) & 140 & 61 & 0 \\
\hline V. parahaemolyticus & ATCC 17802 & Shirasu food poisoning & 93 & 80 & 0 \\
\hline V. tubiashii & ATCC 19106 & Hard clam larvae & 125 & 117 & 0 \\
\hline V. vulnificus biogroup I & TG617 & Diseased shrimp ( $P$. monodon) & 84 & 26 & ND \\
\hline V. vulnificus biogroup II & ATCC 33148 & Diseased eel (Anguilla japonica) & 0 & 0 & 0 \\
\hline \multicolumn{6}{|l|}{ Yeast } \\
\hline Debaryomyces hansenii & QF82-334 & $\begin{array}{l}\text { Giant freshwater prawn } \\
\text { (Macrobrachium rosenbergii) }\end{array}$ & 77 & 78 & 79 \\
\hline D. hansenii & QF83-80 & Giant freshwater prawn ( $M$. rosenbergii) & 90 & 86 & 73 \\
\hline
\end{tabular}

Area of inhibition zone $=\pi r^{2}-$ area of the well. $r$ is the measured radius.

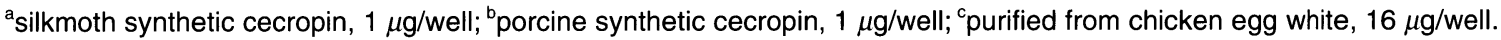
ND: not determined

Table 2. Minimal inhibitory concentration (MIC) and minimal bactericidal concentration (MBC) of cecropin A for the bacteria pathogenic to crustaceans

\begin{tabular}{lrr}
\hline \multicolumn{1}{c}{ Bacterial strain } & $\begin{array}{r}\mathrm{MIC} \\
(\mu \mathrm{M})\end{array}$ & $\begin{array}{r}\mathrm{MBC} \\
(\mu \mathrm{M})\end{array}$ \\
\hline Vibrio vulnificus TG617 (biogroup I) & 7.81 & 15.59 \\
V. harveyi ATCC14126 & 1.95 & 3.90 \\
V. harveyi 13b & 1.95 & 7.81 \\
V. harveyi W36G & 1.95 & 3.90 \\
V. alginolyticus Val & 0.98 & 7.81 \\
Escherichia coli D21 & 0.39 & 0.98 \\
\hline
\end{tabular}

Tabulated values presented are average of two or more independent experiments.

those in $\mathrm{LB}(1 \% \mathrm{NaCl})$, although cecropin $A$ appears to be more potent than the $\mathrm{B}$ form. In $\mathrm{NaCl}$ susceptibility test (Fig. 1), the killing activity of cecropin performed well in a low concentration $(0.1-0.3 \mathrm{M} \mathrm{NaCl})$ but was decreased in a high concentration $(0.5 \mathrm{M} \mathrm{NaCl})$. Kjuul et al. (1999) reported that the antibacterial effect of cecropin peptides was strongly reduced with increased concentration of $\mathrm{NaCl}$ in the growth medium. Kjuul et al. (1999) and Yomogida et al. (1997) concluded that the antibacterial effect of cecropin, and defensin, too, was strongly sensitive to salt. It is most probable that the higher levels of salt interfere with the charge interactions by which the cecropin bind to the bacterial membrane thus inhibiting the activity of these peptides depending on the amount of salt. Because of osmoregulation, the salt content in a marine fish is almost the same as that of freshwater fish hence the peptide might work well in marine fish except in sites such as gill, skin surfaces and the gastro-intestinal tract. However, the aquatic invertebrates with an open circulatory system such as shrimp change their hemolymph osmosis depending upon the external environment. Although cecropin does have anti-Vibrio activity at salt concentrations found in the $\mathrm{NaCl}$-supplemented TSB, the prospect of using cecropins in the treatment of infectious diseases for marine invertebrates needs careful consideration.

Lethal concentrations ranged from $4.5 \mu \mathrm{M}$ for tomato protoplasts to $41 \mu \mathrm{M}$ for sugar beet protoplasts (Nordeen et al., 1992). However, lethal concentration of cecropin for human embryonic lung fibroblastoid cells was reported to be greater than $4 \mu \mathrm{M}$ (Wachinger et al., 


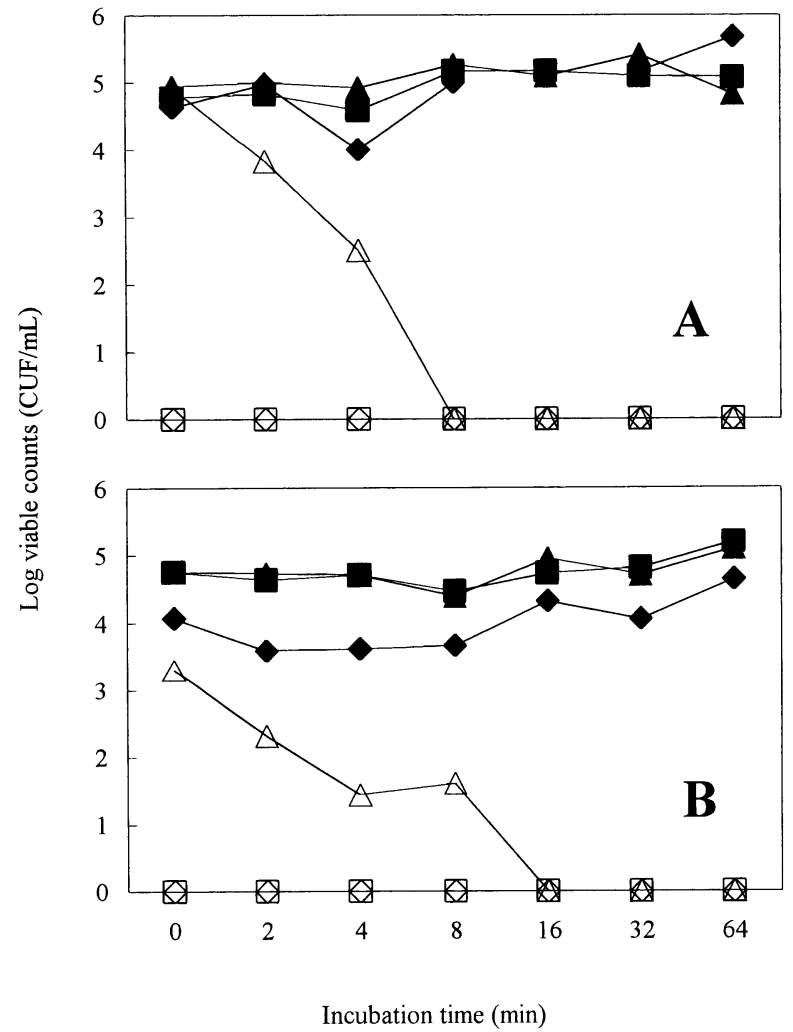

Fig. 1. Influence of $\mathrm{NaCl}$ on bactericidal activity of cecropin $\mathrm{A}$ against (A) Vibrio alginolyticus Val and (B) V. harveyi W36G grown aerobically in tryptic soy broth (TSB). Cecropin was added in experimental groups $(5 \mu \mathrm{M}$ for V. harveyi and $2.5 \mu \mathrm{M}$ for $V$. alginolyticus) (empty symbol); not added in control groups (solid symbol) but TSB was supplemented with the respective $\mathrm{NaCl}$ concentration. $\mathrm{NaCl}$ concentrations were of $0.1 \mathrm{M}$ $(\diamond, \diamond), 0.3 \mathrm{M}(\square, \boldsymbol{\square}), 0.5 \mathrm{M}(\triangle, \Delta)$.

1998) for human liver cells greater than $20 \mu \mathrm{M}$ and for sheep red blood cells greater than $200 \mu \mathrm{M}$ (Steiner et al., 1981). ${ }^{51} \mathrm{Cr}$-release assay showed a cytotoxic effect of cecropin on shrimp hemocytes at concentrations equal to or more than $50 \mu \mathrm{M}$ in this study (Fig. 2). These cytotoxic data indicated that resistance of animal cells to cecropin varied greatly among cell types and species. Nevertheless, there was smaller, but still considerable, difference between the lethal concentrations of cecropin A for shrimp hemocytes and Vibrio pathogens. The lethal concentration of cecropin A for shrimp hemocytes (i.e. $50 \mu \mathrm{M}$ ) is $3.2-$ to 12.8 -fold $\mathrm{MBC}$ for the respective bacterial pathogens (Table 2) such as $V$. vulnificus biogroup I $(15.59 \mu \mathrm{M}), V$. alginolyticus $(7.81 \mu \mathrm{M})$ and $V$. harveyi $(3.90-7.81 \mu \mathrm{M})$. Only is the difference big enough between the lethal concentrations of a peptide for the host and the respective pathogens, the treatment of peptide will be considered safe in transgenic organisms or given passively in vivo to enhance disease resistance against pathogens. Therefore, it may be difficult to engineer a systemic resistance against infection in shrimp using cecropin or cecropin-based genes.

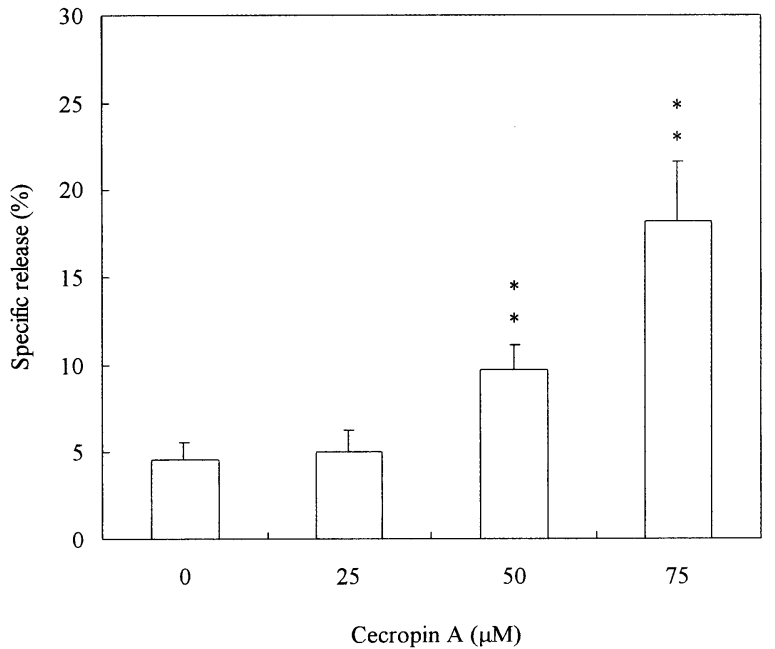

Fig. 2. Cytotoxic effect of cecropin A on shrimp (Penaeus monodon) hemocytes using a ${ }^{51} \mathrm{Cr}$-release assay. Error bar represents standard error of percent specific release values of twenty samples. ${ }^{* *}$ Percent specific release was significantly different between cecropintreated and non-treated hemocytes analyzed statistically using a t-test $(p<0.01)$.

The strong and broad-spectrum antimicrobial activity of cecropin peptides against aquatic pathogens is put into question because their killing activity is sensitive to salt and a small difference between the lethal concentrations of peptide for hemocytes and pathogens suggested that cecropin peptide may be difficult to express or be given passively in vivo for the purpose of treatment of infectious diseases in marine shrimp.

\section{Acknowledgements}

The authors are grateful to Dr. H. G. Boman, Department of Microbiology, Stockholm University, for providing E. coli strains and valuable comments to the radial diffusion method. We appreciate Dr. I-Hsiung Chen, Institute of Biochemistry, Academic Sinica, for kindly providing Gamma counter and isotope facilities. Thanks are also extended to Drs. J. P. Hsu, K. K. Lee and $\mathrm{H}$. Wakabayashi, for donating yeast and bacterial strains. The National Science Council, Republic of China under the grant nos. NSC 83-0211-B-002-005, NSC84-2311-B-002-003 and NSC89-2313-B-002-232 supported this research financially.

\section{References}

Boman, H. G. (1991): Antibacterial peptides: key components needed in immunity. Cell, 65, 205-207.

Bower, S. M., S. E. McGladdery and I. M. Price (1994): Synopsis of infectious diseases and parasites of commercially exploited shellfish. Ann. Rev. Fish Dis., 4, 1-199.

Chalk, R., H. Townson and P. J. Ham (1995): Brugia pahangi: The effects of cecropins on microfilariae in vitro and in Aedes aegypti. Exp. Parasitol., 80, 401-406. 
Cole, A. M., P. Weis and G. Diamond (1997): Isolation and characterization of pleurocidin, an antimicrobial peptide in the skin secretions of winter flounder. J. Biol. Chem., 272, 12008-12013.

Destoumieux, D., P. Bulet, D. Loew, A. V. Dorsselaer, J. Rodriguez and E. Bachere (1997): Penaeidins, a new family of antimicrobial peptides isolated from the shrimp Penaeus vannamei (Decapoda). J. Biol. Chem., 272, 28398-28406.

Dickinson, L., V. Russell and P. E. Dunn (1988): A family of bacteria-regulated, cecropin D-like peptides from Manduca Sexta. J. Biol. Chem., 263, 19424-19429.

Flyg, C., G. Dalhammar, B. Rasmuson and H. G. Boman (1987): Insect immunity: inducible antibacterial activity in Drosophila. Insect Biochem., 17, 153-160.

Hoffmann, D., D. Hultmark and H. G. Boman (1981): Insect immunity: Galleria mellonella and other lepidoptera have cecropia-P9-like factors active against Gram negative bacteria. Insect Biochem., 11, 537-548.

Hogan, R. J., T. B. Stuge, L. W. Clem, N. W. Miller and V. G. Chinchar (1996). Anti-viral cytotoxic cells in the channel catfish (Ictalurus punctatus). Dev. Comp. Immunol., 20, 115-127.

Hultmark, D., H. Steiner, T. Rasmuson and H. G. Boman (1980): Insect immunity, purification and properties of three inducible bactericidal proteins from hemolymph of immunized pupae of Hyalophora cecropia. Eur. J. Biochem., 106, 7-16.

Hultmark, D., A. Engstrom,, H. Bennich, K. Rashmi and H. G. Boman (1982): Insect immunity: Isolation and structure of cecropin $D$ and four minor antibacterial components from Cecropia pupae. Eur. J. Biochem., 127, 207-217.

Hultmark, D., A. Engstrom, K. Anderson, H. Steiner, H. Bennich and H. G. Boman (1983): Insect immunity. Attacins, a family of antibacterial proteins from Hyalophora cecropia. EMBO J., 2, 571-576.

Karunasagar, I., S. K. Otta and I. Karunasagar (1998). Disease problems affecting cultured penaeid shrimp in India. Fish Pathol., 33, 413-420.

Kjuul, A. K., E. E. Bullesbach, S. Espelid, R. Dunham, T. Q. Jorgensen, G. W. Warr and O. B. Styrvold (1999): Effects of cecropin peptides on bacteria pathogenic to fish. $J$. Fish Dis., 22, 387-394.

Lavilla-Pitogo, C. R. and L. D. de la Peña (1998). Bacterial diseases in shrimp (Penaeus monodon) culture in the Philippines. Fish Pathol., 33, 405-421.

Lee, J. Y., A. Boman, S. Chuanxin, M. Anderson, H. Jounvall, V. Mutt and H. G. Boman (1989): Antibacterial peptides from pig intestine: isolation of a mammalian cecropin. Proc. Natl. Acad. Sci. USA., 86, 9159-9162.

Lightner, D. V. and R. M. Redman (1998): Strategies for the control of viral diseases of shrimp in the Americas. Fish Pathol., 33, 165-180.

Lu, C. C., K. F. J. Tang and S. N. Chen (1998): Identification and genetic characterization of yeasts isolated from freshwater prawns, Macrobrachium rosenbergii de Man, in Taiwan. J. Fish Dis., 21, 185-192.

Matsumoto, N., M. Okada, H. Takahashi, Q. X. Ming, Y. Nakanishi, Y. Nakajima, H. Komano and S. Natori (1986): Molecular cloning of a cDNA and assignment of the C-ter- minal of sarcotoxin IA, a potent antibacterial protein of Sarcophaga peregrina. Biochem. J., 239, 717-722.

Mohney, L. L., D. V. Lightner and T. A. Bell (1994): An epizootic of vibriosis in Equadorian pond-reared Penaeus vannamei Boone (Crustacea: Decapoda). J. World Aquacult. Soc., 25, 116-125.

Morishima, I., S. Suginaka, T. Ueno and H. Hirano (1990). Isolation and structure of cecropins, inducible antibacterial peptides, from the sikworm Bombyx mori. Comp. Biochem. Phys., 95B, 551-554.

Munday, B. L. and L. Owens (1998): Viral diseases of fish and shellfish in Australian mariculture. Fish Pathol., 33, 193200.

Nordeen, R. O., S. T. Sinden, J. M. Jaynes and L. D. Owens (1992): Activity of cecropin SB37 against protoplasts from several plant species and their bacterial pathogens. Plant Sci., 82, 101-107.

Qu, X., H. Steiner, A. Engstrom, G. Bennich and H. G. Boman (1982): Insect immunity: Isolation and structure of cecropins $B$ and $D$ from pupae of the Chinese oak silk moth, Antheraea pernyi. Eur. J. Biochem., 127, 219-224.

Samakovlis, C., D. A. Kimbrell, P. Kylsten, A. Engstrom and D. Hultmark (1990): The immune response in Drosophila: pattern of cecropin expression and biological activity. EMBO J., 9, 2969-2976.

Song, Y. L. and S. P. Lee (1993): Characterization and ecological implication of luminous Vibrio harveyi isolated from tiger shrimp (Penaeus monodon). Bull. Institute Zoology, Academic Sinica, 32, 217-220.

Song, Y. L., W. Cheng, C. H. Shen, Y. C. Ou and H. H. Sung (1990): Occurrence of Vibrio vulnificus infections in cultured shrimp and eel in Taiwan. Proc. ROC-Japan Symp. Fish Dis., 172-179.

Steiner, H., D. Hultmark, A. Engstrom, H. Bennich and H. G. Boman (1981): Sequence and specificity of two antibacterial proteins involved in insect immunity. Nature 292 , 246-248.

Takahashi, Y., T. Itami, M. Maeda and M. Kondo (1998). Bacterial and viral diseases of kuruma shrimp (Penaeus japonicus) in Japan. Fish Pathol., 33, 357-364.

Wachinger, M., A. Kleinschmidt, D. Winder, N. von Pechmann, A. Ludvigsen, M. Neumann, R. Holle, B. Salmons, V. Erfle and R. Brack-Werner (1998): Antimicrobial peptides melittin and cecropin inhibit replication of human immunodeficiency virus 1 by suppressing viral gene expression. J. Gen. Virol., 79, 731-740.

Wang, Y. C. and P. S. Chang (2000): Yellow head virus infection in the giant tiger prawn Penaeus monodon cultured in Taiwan. Fish Pathol., 35, 1-10.

Yomogida, S., I. Nagaoka and T. Yamashita (1997): Purification of the 11-and 5-kDa antibacterial polypeptides from guinea pig neutrophils. Arch. Biochem. Biophys., 328, 219-226.

Zaldivar, M. (1985). Attachment of the pathogen Flexibacter columnaris to fish cells. Master thesis, Oregon State Univ., Corvallis, 65pp.

Zasloff, M. (1987): Magainins, a class of antimicrobial peptides from Xenopus skin: isolation, characterization of two active forms, and partial cDNA sequence of a precursor. Proc. Natl. Acad. Sci. USA. 84, 5449-5453. 